\title{
Presurgical orthodontic treatment of newborns with deficiency of body weight
}

\author{
O.V.Dudnik, Ad.A.Mamedov, N.A.Geppe, A.A.Skakodub, O.T.Zangieva, \\ Yu.V.Stebeleva, Guo Hao, D.S.Bille, A.S.Chertikhina, A.R.Beznosik \\ I.M.Sechenov First Moscow State Medical University (Sechenov University), Moscow, Russian Federation
}

\begin{abstract}
The study discusses the importance of interdisciplinary approach of pediatricians, surgeons, orthodontists, anesthesiologists and otorhinolaryngologists in the complex rehabilitation of newborns with bilateral cleft lip and palate.

The aim of the study was to increase the effectiveness of treatment of newborns with bilateral cleft lip and palate through preliminary orthodontic preparation. This study clearly emphasizes that the conduction of early pre-surgical orthodontic treatment with the use of individual obturators contributes to the high-quality implementation of further surgical intervention and allows to normalize the act of breastfeeding in newborns. It has been proven that the interdisciplinary approach of doctors of related specialties helps to carry out a comprehensive diagnosis, counseling and subsequent treatment of newborns with bilateral cleft lip and palate. Thus, the integrated approach developed by related specialists in the neonatal period makes it possible to implement a highly qualified and step-by-step treatment from birth up to 18 years of age.

Key words: bilateral cleft lip and palate, newborns, individual obturator, pediatrics, feeding, cheiloplasty, orthodontics
\end{abstract}

For citation: Dudnik O.V., Mamedov Ad.A., Geppe N.A., Skakodub A.A., Zangieva O.T., Stebeleva Yu.V., Hao Guo, Bille D.S., Chertikhina A.S., Beznosik A.R. Presurgical orthodontic treatment of newborns with deficiency of body weight. Vopr. prakt. pediatr. (Clinical Practice in Pediatrics). 2021; 16(1): 36-40. (In Russian). DOI: 10.20953/1817-7646-2021-1-36-40

\section{Предхирургическая ортодонтическая помощь новорожденным с дефицитом массы тела}

\author{
О.В.Дудник, Ад.А.Мамедов, Н.А.Геппе, А.А.Скакодуб, О.Т.Зангиева, \\ Ю.В.Стебелева, Го Хао, Д.С.Билле, А.С.Чертихина, А.Р.Безносик
}

Первый Московский государственный медицинский университет им. И.М.Сеченова (Сеченовский Университет), Москва, Российская Федерация

В исследовании рассматривается важность междисциплинарного подхода педиатров, хирургов, ортодонтов, анестезиологов и оториноларингологов в комплексной реабилитации новорожденных детей с двусторонней расщелиной губы и неба.

Целью исследования было повысить эффективность лечения новорожденных с двусторонней расщелиной губы и неба посредством предварительной ортодонтической подготовки. Данное исследование четко подчеркивает, что проведение раннего предоционного ортодонтического лечения с использованием индивидуальных обтураторов способствует качественной реализации дальнейшего оперативного вмешательства и позволяет нормализовать акт грудного вскармливания у новорожденных. Доказано, что междисциплинарный подход врачей смежных специальностей помогает проводить комплексную диагностику, консультирование и последующее лечение новорожденных с двусторонней расщелиной губы и неба. Таким образом, разработанный грамотный подход смежных специалистов в период новорожденности дает возможность осуществлять высококвалифицированное и поэтапное лечение от рождения до 18 лет. Ключевые слова: двустороння расщелина губы и неба, новорожденные, индивидуальный обтуратор, педиатрия, кормление, хейлопластика, ортодонтия

Для цитирования: Дудник О.В., Мамедов Ад.А., Геппе Н.А., Скакодуб А.А., Зангиева О.Т., Стебелева Ю.В., Хао Го, Билле Д.С., Чертихина А.С., Безносик А.Р. Предхирургическая ортодонтическая помощь новорожденным с десицитом массы тела. Вопросы практической педиатрии. 2021; 16(1): 36-40. DOI: 10.20953/1817-7646-2021-1-36-40

\section{For correspondence:}

Olesya V. Dudnik, MD, PhD, Associate Professor at the Department of Pediatric Dentistry and Orthodontics of the E.V.Borovsky Institute of Dentistry, I.M.Sechenov First Moscow State Medical University (Sechenov University)

Address: 11 Mozhaysky Val str., Moscow, 121059, Russian Federation Phone: (499) 243-4372

E-mail: oldudnik87@mail.ru

ORCID: 0000-0001-7150-9216

The article was received 19.12.2020, accepted for publication 26.02.2021

\author{
Для корреспонденции: \\ Дудник Олеся Викторовна, кандидат медицинских наук, доцент кафедры \\ стоматологии детского возраста и ортодонтии Института стоматологии \\ им. Е.В.Боровского Первого Московского государственного медицинского \\ университета им. И.М.Сеченова (Сеченовский Университет) \\ Адрес: 121059, Москва, ул Можайский Вал, д. 11 \\ Телесон: (499) 243-4372 \\ E-mail: oldudnik87@mail.ru \\ ORCID: 0000-0001-7150-9216 \\ Статья поступила 19.12.2020 г., принята к печати 26.02.2021 г.
}


C left lip and palate is one of the most common orofacial defects. According to the Russian Health Organization, this pathology takes 3rd place in terms of prevalence among congenital anomalies and 1st place in terms of the severity of lesions of anatomical and functional structures. The birth rate of children with cleft lip and palate ranges from 1: 500 to 1: 1000 newborns. The most severe form among them is bilateral cleft lip and palate, which occurs with a frequency of $15 \%$.

The specialists are aimed at restoring functional continuity of the maxillofacial area and favorable esthetic result. Pediatricians, orthodontists and doctors of related branches try to do their best to achieve these results.

Anatomical defect of children with cleft lip and palate leads to functional disorders. Newborns with cleft lip and palate have to face such functional disorders as sucking and feeding [1, 2, 3, 4]. It should be noticed that a balanced diet is the most important aspect that ensures the growth and development of a newborn. Nowadays, the problem of weight deficiency in newborns with this pathology is really relevant because of the difficulty of balanced diet caused by the fact that the nasal cavity has a wide communication with the oral cavity. In addition, feeding is accompanied by aspiration, which further contributes to pathological disorders in motor function of the ciliated epithelium.

Newborns with cleft lip and palate have impaired functions of sucking, swallowing and breathing, as well as nasal regurgitation of food, excessive air consumption, and an acceptable level of suction and compression required for artificial or breast-feeding [3]. Inability in well-balanced diet can lead to growth disorders, cause possible delays in surgical recovery and have long-term negative consequences for cognitive development (Corbett and Drewett, 2004).

After studying national and foreign publications on this issue, it was found that up to $43 \%$ of newborns with cleft lip and palate have a risk of complications due to underweight [3-9]. Feeding using a bottle or a probe does not allow to achieve the necessary weight gain for the possibility of general anesthesia, which is necessary at the stage of primary surgical operation of cheiloplasty. This is one of the urgent problems that needs to be solved in the first months of life.

A complex rehabilitation program for children with congenital malformations and abnormalities of the cranio-maxillofacial area should include an interdisciplinary approach of neonatologists, pediatricians, surgeons, orthodontists, anesthesiologists and otorhinolaryngologists $[1,10]$.
In this regard, early pre-surgical orthodontic treatment is one of the particular importance in order to create conditions for obtaining the well-balanced diet from the first weeks of birth of children with this pathology $[5,6,10,11]$.

Objective. The aim of the study was to increase the effectiveness of the treatment of infants with bilateral cleft lip and palate with underweight due to pre-orthodontic preparation.

\section{Patients and Methods}

During the study, 53 newborns were examined with a diagnosis of bilateral cleft lip and palate. Thirty-two of them were included into the treatment group and divided further into two groups. The first group consisted of 16 infants who were manipulated with an anatomical nipple. The second group of patients consisted of 16 people, who underwent pre-surgical orthodontic treating on individual obturators, which allowed to use breastfeeding.

Patients from both groups underwent a following standard clinical and diagnostic examination:

1. The clarification of complaints.

2. Collecting anamnesis.

3. Examination of the general somatic condition of the patient

4. Photometric analysis (Fig. 1. a, b, c).

5. Examination of the maxillofacial area (the shape and the structure of the skull, the condition of soft tissues, the severity of nasolabial folds, the assessment of lip symmetry and the thickness and assessment of the shape of the nose) was performed in profile and full-face.

6. Assessment of the oral cavity and the vestibule of the mouth itself.

7. Assessment of the condition of imperforate alveolar processes.

8. Anthropometric study of diagnostic models.

9. Preparation of a comprehensive treatment plan.

The interdisciplinary approach included consultation with a neonatologist, pediatrician, surgeon, orthodontist, anesthesiologist and otorhinolaryngologist. It should be noted that bilateral cleft lip and palate in most cases is accompanied by otolaryngological pathology, which does not appear immediately, but closer to one year of the baby's life.

After a complex examination and the decision of a specialist consultation, all 32 newborns with bilateral cleft lip and palate

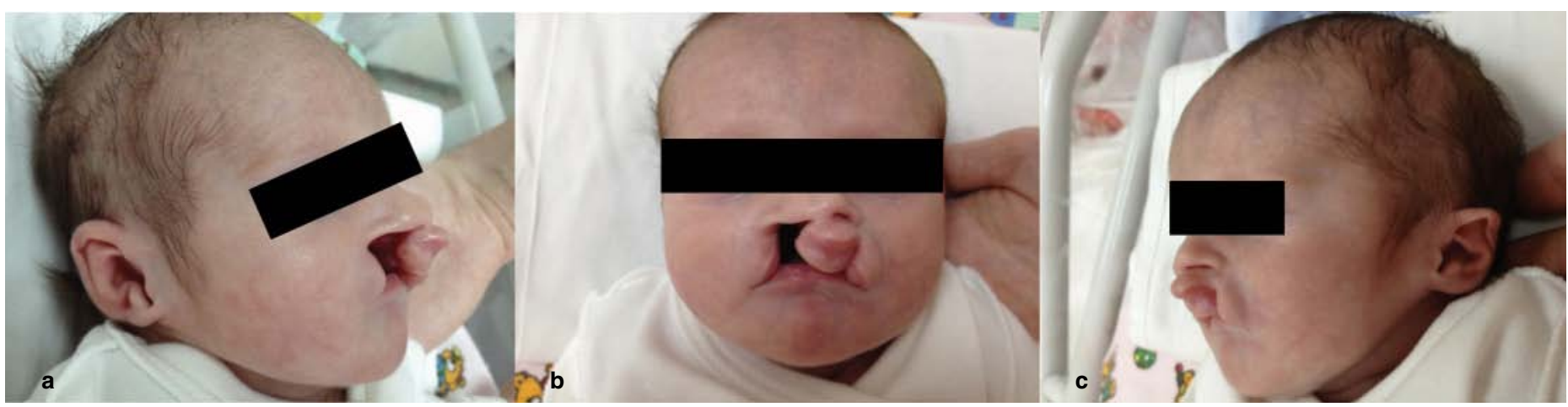

Figure 1. Photometric analysis of the face in profile (a, c), full-face (b)

Рисунок 1. Фотометрический анализ лица в профиль (a, c), в анфас (b) 


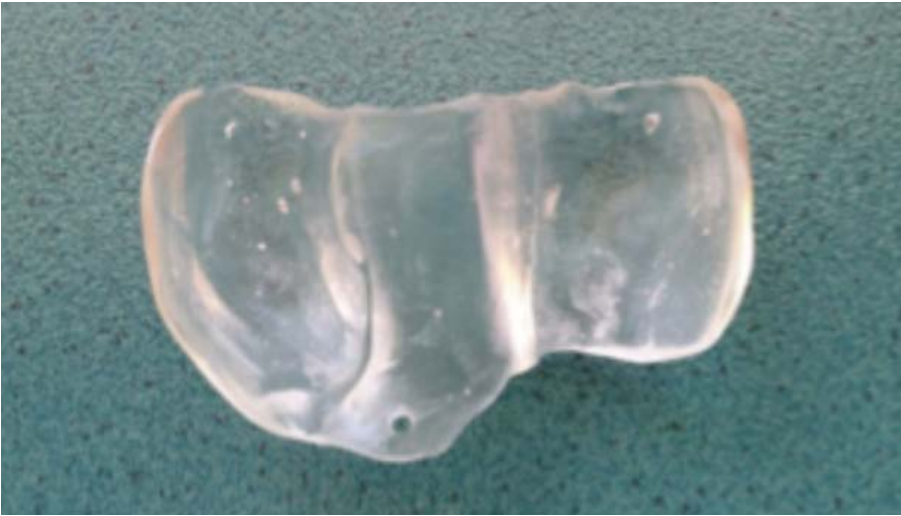

Fig. 2. Orthodontic plate obturator.

Рис. 2. Ортодонтический пластиночный обтуратор.

underwent primary cheiloplasty with preliminaries. Due to the complex approach, the newborns gained the necessary weight with this pathology and were ready for surgery, including pregeneral anesthesia.

While patients of the first group were fed in the traditional way using an anatomical nipple, the

patients of the second group were treated by the following orthodontic protocol:

1. Taking an impression from the upper jaw.

2. Making a diagnostic model.

3. Making an individual spoon, based on the diagnostic model, which later provided an accurate impression for modeling an individual obturator.

4. Removal of a repeat precise impression, production of a diagnostic model.

5. Modeling of an orthodontic plate-type obturator (Fig. 2).

6. Fixation of the obturator in the oral cavity (Fig. 3). As an exception to the risk of aspiration by the device, it was fixed with an atraumatic thread.

After the infants reached the necessary weight, patients in both groups underwent primary cheiloplasty using the method of Adil Askerovich Mamedov.

\section{Results and discussion}

The results of this research clearly demonstrated the need for a complex interdisciplinary diagnosis and follow-up conversations between pediatricians, surgeons, orthodontists and doctors of related specialties with parents of newborns with this pathology.

Feeding newborns with cleft lip and palate in the first hours and days since birth especially requires quick and precise guidelines from doctors [3, 4]. In this situation, parents are usually very upset and confused. It can be difficult for them to formulate questions. This is why it is so important to provide a complex approach to the survey, consultation and treatment of children with this pathology $[1,2,5]$.

The results of the research showed that all 32 children (100\%) had an acute weight loss after born, which did not allow general anesthesia to be performed for primary surgical intervention. During the research, the survey of children's parents with this pathology revealed that $100 \%$ of mothers needed special training in feeding skills and oral care.

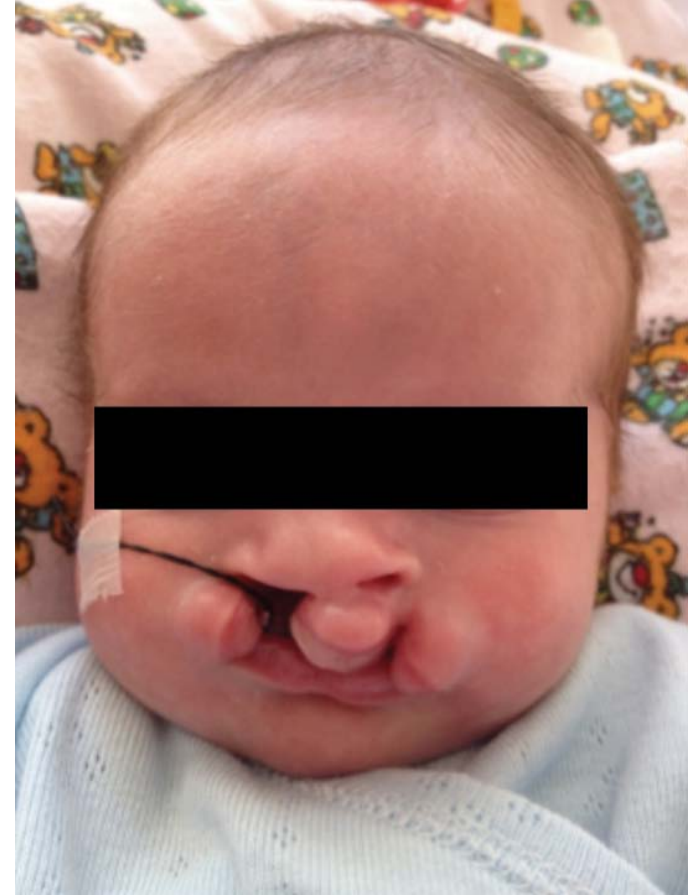

Fig. 3. The orthodontic plate obturator is fixed in the oral cavity.

Рис. 3. Ортодонтический пластиночный обтуратор зафиксирован в полости рта.

Clinical and biometric dates of patients in the first group, who were fed using anatomical nipples, showed that in $87.5 \%$ of cases (14 patients), it was not possible to develop a well-balanced diet. When the milk or food mixture entered the baby's oral cavity, some of it entered the nose, since the nipple did not establish total isolation of the mouth from the nasal cavity. As a result, the children were nervous, often crying, and refused to be fed. The reason of such behavior is a great variety of disorders of digastric system which were caused because of a large amount of air getting into the stomach. Children's worries were transmitted to their parents, and a perverse cycle was created. All these factors did not allow quick and effective weight gain in these patients, and as a result surgery was delayed for a long period of time. And only $2(12.5 \%)$ newborns from the first group could quickly and efficiently gained weight and got used to diet. We, in turn, associate this with the fact that these parents have already had enough manual feeding skills, because of a high lifetime experience being parents.

Data analysis of patients from the second group, who were given individual orthodontic obturators, showed that all $16(100 \%)$ newborns managed to establish feeding. It should be noted that $15(93.75 \%)$ patients were fully nursed, and 1 newborn was artificially fed using a bottle with an anatomical nipple due to the absences of breastfeeding.

Also, newborns from the second group who got used to breastfeeding were calm and easygoing. Natural feeding has a beneficial effect on the child's nervous system, making it more flexible [3,4]. Emotional contact with the mother, close connection with her - all this created a positive background between the baby and the parents.

Evidence from multiple studies shows that a nursing mother gets satisfaction from feeding, and she is more harmonious and 
delightful. Nursing also has a positive effect on her nervous system, which is also passed on to the baby [12].

In addition, when a child is sucking breast, these movements trigger the physiological growth and development of the lower jaw. The movement of the lower jaw is the following: firstly, down and then moved forward, while the tongue makes wave-like movements during sucking, at this moment, the muscles of the tongue, the bottom of the oral cavity, facial muscles are also involved $[4,5,8]$. The most important moment for the healthy development of the maxillofacial zone is that during breast-sucking, the child learns the physiologically correct movement of the tongue [9].

Independent experts of the Department of Pediatric Dentistry and Orthodontics of the University of Sao Paulo (Brazil) in April 2011 conducted a survey of 1377 children and concluded that breast-feeding for more than 12 months reduced the risk of malocclusion by 3.7 times.

The same conclusions were reached by researchers from Hong Kong, where the results of an examination of 851 children found that children who were breastfed had a lower risk of different malocclusions. The results of the study were published in the scientific article "The effect of breastfeeding on the formation of the dental arch" in March 2015.

Therefore, the experience of pediatricians and dentists on a global scale, as well as the latest scientific research in the field of pediatrics, dentistry and orthodontics, determines breast-feeding as a protective factor against several general somatic pathologies and malocclusions.

Timely orthodontic treatment in the early stages of bilateral cleft palate allows to control and stimulate the development of the upper jaw, ensuring a balanced interaction of the dental arches in the early stages of jaw growth. Presurgical orthodontic treatment creates favorable conditions for general anesthesia and further plastic surgery of the palate.

This study proves that the conduction of cheiloplasty by Ad.A. Mamedov during the perinatal period contributes to the normalization and recovery of sucking function in newborns with bilateral cleft lip and palate. Normalization of the relative position of the upper jaw fragments creates favorable conditions for normal infant feeding, including by breast-feeding, which contributes to the healing of postoperative wounds, normalizing weight gain, and improves the psycho-emotional mood of the family as a whole.

\section{Conclusion}

Therefore, the interdisciplinary approach of pediatricians, surgeons, orthodontists, anesthesiologists and otorhinolaryngologists allows to carry out the complex diagnostics, consultation and follow-up treatment of newborns with bilateral cleft lip and palate. The development of an integrated approach during the perinatal period allows specialists to realize a well-founded stepby-step treatment from the moment of birth to 18 years of age.

These researches visually emphasize that early pre-surgical orthodontic treatment with individual obturators allows to normalize the act of breastfeeding in newborns, which contributes to surgical intervention. Insertion of individual obturators into the oral cavity, in addition to preparing for surgical treatment, allows to normalize the feeding process, fix the sucking reflex and establish emotional contact between the mother and the child, as a close connection between parents and children creates a positive background between all members of family. This plays a beneficial effect on the child's nervous system and its further development.

\section{Financial support}

No financial support has been provided for this work.

\section{Информация о финансировании}

Финансирование данной работы не проводилось.

\section{Конфрликт интересов}

Авторы заявляют об отсутствии конфрликта интересов.

\section{Conflict of interests}

The authors declare that there is no conflict of interest.

\section{Informed consent}

In carrying out the study, written informed consent was obtained from all patients or their parents or legal representatives.

\section{Информированное согласие}

При проведении исследования было получено информированное согласие пациентов или их родителей либо законных представителей.

\section{References}

1. Arsenina OI, Malashenkova El, Pashchenko SA. Algorithm of orthodontic treatment of cleft lip and palate patients before and after autogenous bone grafting. Stomatology. 2017;96(5):62-5. (In Russian). DOI: 10.17116/stomat 201796562-65

2. Bogoroditskaya AV, Sarafanova ME, Radcig EY, Prityko AG. Clinical management of children with congenital cleft lip and palate: an interdisciplinary problem. Journal "Pediatria" named after G.N. Speransky.2015;94(3):78-80. (In Russian).

3. Kosolapov Al, Lobastov DK. Vliyanie grudnogo vskarmlivaniya na nervnopsihicheskoe razvitie detej pervogo goda zhizni. Materinstvo i detstvo, 2013:41. (In Russian).

4. «Zdravoohranenie v Rossii» Federal'naya sluzhba gosudarstvennoj statistiki. Moskva.2017:59. (In Russian).

5. Mamedov AA, Supiyev TK, Negametzyanov NG. Vrozhdonnaya rasshchelina verkhney guby i neba [Congenital Cleft Lip and Palate]. Almaty,2013:100-105. (In Russian).

6. Mamedov AA. Podderzhka reshenij vracha pri lechenii detej s vrozhdennoj rasshchelinoj guby i neba. Vrach i informacionnye tekhnologii. 2007; 6:28-32. (In Russian).

7. Kenneth ES, Shai MR, Edward RG, David GG. Unilateral Cleft Lip-Approach and Technique. Semin Plast Surg. 2005 Nov;19(4): 313-328. DOl: 10.1055/s- 2005925904

8. Pandya AN, Boorman JG. Failure to thrive in babies with cleft lip and palate. $\mathrm{Br} \mathrm{J}$ Plast Surg. 2001;54(6):471-475. DOl: 10.1054/bjps.2001.3618

9. Stock NM. et all. Teachers' Perspectives on the impact of the Cleft lip and/or palate during the school years. The Cleft palate-craniofacial journal: official publication of the American Cleft Palate-Craniofacial Association. 2019;56(2):204209. DOI: $10.1177 / 1055665618770191$

10. Hrichanyuk DA, Chuykin SV, Davletshin NA, Makusheva NV.Surgical treatment of congenital cleft lips in children.Actual problems in dentistry. 2018;14(1):99-105. DOI: 10.24411/2077-7566-2018-100018

11. Mamedov AA, Maclennan AB, Blinder ZA, Mazurina LA. Surgical treatment of children with cleft lip and palate in newborn period, Transactions of 10th World 
Cleft Lip and Palate Congress (ICPF) Diagnosis, Prevention, Genetics and Mamegement of Cleft and Craniofacial Deformities. Current Techniques, research and Future directions. 2016,24-28 0ct; Chenna, India:117.

12. Shumatova TA, Grigoryan LA, Prikhodchenko NG. Analyzing the breast-feeding mode as a factor of atopy. Pacific Medical Journal.2010;1:34-7. (In Russian).

\section{Information about authors:}

Adil A. Mamedov, MD, PhD, DSc, Professor, Head of the Department

of Pediatric Dentistry and Orthodontics of the E.V.Borovsky Institute of Dentistry, I.M.Sechenov First Moscow State Medical University (Sechenov University) Adress: 11 Mozhaysky Val str., Moscow, 121059, Russian Federation

Phone: (495) 609-1400

E-mail: mmachildstom@mail.ru

ORCID: 0000-0001-7257-0991

Natalya A. Geppe, MD, PhD, DSc, Professor, Head of the Department of Childhood Diseases of the N.F.Filatov Clinical Institute of Children's Health, I.M.Sechenov First Moscow State Medical University (Sechenov University) E-mail: geppe@mail.ru

ORCID: https://orcid.org/0000-0003-0547-3686

Alla A. Skakodub, MD, PhD, Associate Professor of Dentistry

at the Department of Pediatric Dentistry and Orthodontics of the E.V. Borovsky Institute of Dentistry, I.M.Sechenov First Moscow State Medical University (Sechenov University)

E-mail: skalla71@mail.ru

ORCID: https://orcid.org/0000-0003-4530-4721

Olga T. Zangieva, Assistant at the Department of Pediatric Dentistry and Orthodontics of the E.V.Borovsky Institute of Dentistry, I.M.Sechenov First Moscow State Medical University (Sechenov University)

E-mail: olga.dok.oz@gmail.com

ORCID: https://orcid.org/0000-0001-7294-5247

Yulia V. Stebeleva, Assistant at the Department of Pediatric Dentistry and Orthodontics of the E.V.Borovsky Institute of Dentistry, I.M.Sechenov Firs Moscow State Medical University (Sechenov University)

E-mail: julchensteb @ mail.ru

ORCID: https://orcid.org/0000-0003-1340-527X

Guo Hao, Assistant at the Department of Pediatric Dentistry and Orthodontics of the E.V.Borovsky Institute of Dentistry, I.M.Sechenov First Moscow State Medical University (Sechenov University)

E-mail: 1402900673@qq.com

Diana S. Bille, Student of the I.M.Sechenov First Moscow State Medical University (Sechenov University)

E-mail: dsaprano@mail.ru

ORCID: 0000-0002-8222-5419

Arina S. Chertikhina, Student of the I.M.Sechenov First Moscow State Medical University (Sechenov University)

E-mail: Cherarina7@gmail.com

ORCID: 0000-0003-1798-9487

Alexandra R. Beznosik, Student of the I.M.Sechenov First Moscow State Medical University (Sechenov University)

E-mail: bez.al@rambler.ru

ORCID: 0000-0001-6878-8410

\section{Информация о соавторах:}

Мамедов Адиль Аскерович, доктор медицинских наук, профрессор, заведующий кафедрой стоматологии детского возраста и ортодонтии Института стоматологии им. Е.В.Боровского Первого Московского государственного медицинского университета им. И.М.Сеченова (Сеченовский Университет), Заслуженный врач РФ

Адрес: 121059, Москва, ул Можайский Вал, д. 11

Телесон: (495) 609-1400

E-mail: mmachildstom@ mail.ru

ORCID: 0000-0001-7257-0991

Геппе Наталья Анатольевна, доктор медицинских наук, профессор, заведующая кафедрой детских болезней Клинического института детского здоровья Н.Ф.Филатова Первого Московского государственного

медицинского университета им. И.М.Сеченова (Сеченовский Университет),

Заслуженный врач РФ

E-mail: geppe@ mail.ru

ORCID: https://orcid.org/0000-0003-0547-3686

Скакодуб Алла Анатольевна, кандидат медицинских наук, доцент кафедры стоматологии детского возраста и ортодонтии Института стоматологии

им. Е.В.Боровского Первого Московского государственного медицинского университета им. И.М.Сеченова (Сеченовский Университет)

E-mail: skalla71@mail.ru

ORCID: https://orcid.org/0000-0003-4530-4721

Зангиева Ольга Таймуразовна, ассистент кафедры стоматологии детского возраста и ортодонтии Института стоматологии им. Е.В.Боровского

Первого Московского государственного медицинского университета

им. И.М.Сеченова (Сеченовский Университет)

E-mail: olga.dok.oz@gmail.com

ORCID: https://orcid.org/0000-0001-7294-5247

Стебелева Юлия Валерьевна, ассистент кафедры стоматологии детского возраста и ортодонтии Института стоматологии им. Е.В.Боровского Первого Московского государственного медицинского университета им. И.М.Сеченова (Сеченовский Университет)

E-mail: julchensteb@mail.ru

ORCID: https://orcid.org/0000-0003-1340-527X

Го Хао, ассистент кафедры стоматологии детского возраста и ортодонтии Института стоматологии им. Е.В.Боровского Первого Московского государственного медицинского университета им. И.М.Сеченова

(Сеченовский Университет)

E-mail: 1402900673@qq.com

Билле Диана Сергеевна, студентка Первого Московского государственного медицинского университета им. И.М.Сеченова (Сеченовский Университет) E-mail: dsaprano@mail.ru

ORCID: 0000-0002-8222-5419

Чертихина Арина Сергеевна, студентка Первого Московского государственного медицинского университета им. И.М.Сеченова

(Сеченовский Университет)

E-mail: Cherarina7@ gmail.com

ORCID: 0000-0003-1798-9487

Безносик Александра Романовна, студентка Первого Московского государственного медицинского университета им. И.М.Сеченова (Сеченовский Университет)

E-mail: bez.al@ rambler.ru

ORCID: 0000-0001-6878-8410

\section{Издательство «Династия» \\ выпускает научно-практический журнал Национального научного общества инфекционистов «Инфекционные болезни»}
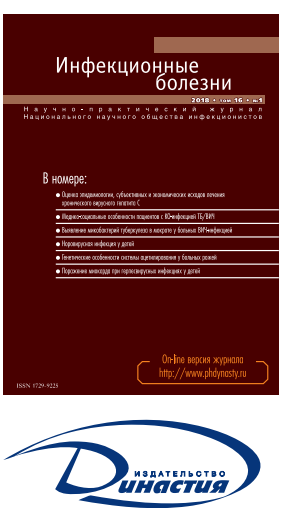

www.phdynasty.ru

\section{Главный редактор}

академик РАН, профессор В.В.Малеев

советник директора по научной работе Центрального НИИ эпидемиологии Роспотребнадзора

\section{Заместители главного редактора}

член-корреспондент РАН, профессор А.В.Горелов

заместитель директора по научной работе Центрального НИИ эпидемиологии Роспотребнадзора академик РАН, профессор В.В.Покровский

руководитель Федерального научно-методического центра по профилактике и борьбе со СПиДом

Журнал ориентирован на широкий круг специалистов - инфекционистов, терапевтов, участковых и семейных врачей,

педиатров, научных работников, преподавателей ВУЗов, организаторов здравоохранения. На страницах журнала обсуждаются

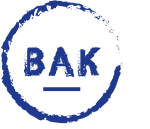

Scopus

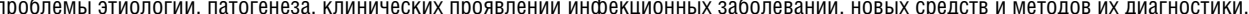

профилактики и лечения (включая антибактериальную и противовирусную терапию, использование иммуноглобулинов и интерсеронов,

а также интенсивную терапию неотложных состояний).

Журнал индексируется в международной реферативной базе данных Scopus, Ulrich's Periodicals Directory

и в Российском индексе научного цитирования. Журнал входит в Перечень ведущих научных журналов и изданий ВАК.

Адрес: 119019, Москва, Г-19, а/я 229, Издательство «Династия». тел./сракс: (495) 660-6004, e-mail: red@phdynasty.ru

По вопросам подписки обращаться: тел./фракс: (495) 660-6004, e-mail: podpiska@phdynasty.ru

отдел рекламы: тел.: (495) 517-7055, тел./факс: (495) 660-6004, e-mail: reklama@phdynasty.ru 